\title{
Emerging role of PET in the diagnosis and staging of lung cancer
}

\author{
Geoffery Coates MB BS MSc FRCPC, Stephen J Skehan MB FFRRSCI, \\ Department of Nuclear Medicine, McMaster University, Hamilton, Ontario
}

\section{G Coates, SJ Skehan. Emerging role of PET in the diag- nosis and staging of lung cancer. Can Respir J 1999;6(2):145-152.}

Positron emission tomography (PET) with ${ }^{18}$ F-fluoro-2deoxyglucose (FDG) has recently emerged as a practical and useful imaging modality in patients with lung cancer. Malignant tumours demonstrate increased uptake of FDG, a positron-emitting radiopharmaceutical. This increased FDG uptake in tumours can be seen using PET. FDG PET has much higher accuracy than other imaging modalities for the differentiation of benign and malignant lung nodules. The sensitivity of PET is $96 \%$ and the specificity $77 \%$ for diagnosing malignant nodules. PET is also more accurate than computed tomography (CT) for staging mediastinal nodal involvement (sensitivity $89 \%$, specificity $94 \%$ ). While CT relies on an arbitrary anatomical cutoff of $1 \mathrm{~cm}$ to diagnose malignant nodes, which may simply be enlarged due to inflammation, PET can accurately diagnose metastases in nodes smaller than $1 \mathrm{~cm}$. Several studies have shown significantly better staging of distant metastases with FDG PET than with traditional techniques such as bone scanning. Differentiation of recurrent disease from scar tissue in the postoperative patient is often difficult with CT or magnetic resonance imaging. The low uptake of FDG in scar tissue allows reliable differentiation between scar tissue and a recurring tumour with PET. Early studies suggest a promising role for PET in the evaluation of response to chemotherapy. This may allow treatment to be changed after only one course of chemotherapy, instead of waiting for anatomical disease progression to become obvious clinically or with $\mathrm{CT}$. Finally, significant improvements in cost effectiveness have been demonstrated when FDG PET is added to the preoperative work-up of patients with lung cancer.

Key Words: Coin lesion, Deoxyglucose, Diagnostic use, Emissioncomputed tomography, Lung neoplasms, Radionuclide imaging

\section{Rôle émergent de la TEP dans le diagnostic et la stadification du cancer du poumon}

RÉSUMÉ : La tomographie par émission de positrons (TEP) avec ${ }^{18}$ F-fluoro-2-déxosyglucose (FDG) a récemment fait son apparition comme modalité d'imagerie pratique et utile chez les patients atteints d'un cancer du poumon. Les tumeurs malignes captent davantage le FDG, produit radiopharmaceutique à émission de positrons. Ce phénomène peut s'observer par TEP. La TEP avec FDG est beaucoup plus précise que les autres modalités d'imagerie pour la différenciation entre nodules pulmonaires bénins et malins. La sensibilité du TEP est de $96 \%$ et sa spécificité est de $77 \%$ pour le diagnostic des nodules malins. La TEP est aussi plus précise que la tomographie pour la stadification de l'atteinte des ganglions médiastinaux (sensibilité $89 \%$, spécificité $94 \%$ ). Si la tomographie repose sur un seuil anatomique arbitraire de $1 \mathrm{~cm}$ pour le diagnostic des ganglions envahis qui peuvent être simplement hypertrophiés en raison de l'inflammation, la TEP offre, pour sa part, un diagnos-

voir page suivante

Correspondence and reprints: Dr Geoffrey Coates, Department of Nuclear Medicine, McMaster University, 1200 Main Street West, Hamilton, Ontario L8N 3Z5. Telephone 905-521 2100 ext 5667, fax 905-521 2358, e-mail coates@ Exchangel.imh.on.ca 
tic précis des métastases dans des ganglions de moins de $1 \mathrm{~cm}$. Plusieurs études ont confirmé la qualité significativement plus grande de la stadification des métastases distales par TEP avec FDG que par les techniques classiques comme la scintigraphie osseuse. La différenciation de la maladie récurrente des tissus cicatriciels chez le patient opéré est souvent difficile par tomographie ou par imagerie par résonance magnétique. La faible captation du FDG par le tissu cicatriciel permet de distinguer avec assez de certitude le tissu cicatriciel d'une tumeur récurrente avec la TEP. Selon les études préliminaires, la TEP a un rôle prometteur pour l'évaluation de la réponse à la chimiothérapie. Cela permettrait de modifier le traitement après une seule cure de chimiothérapie plutôt que d'attendre que la maladie progresse sur le plan anatomique au point d'être mise en évidence par des signes cliniques ou par la scintigraphie. Finalement, on a noté des améliorations significatives sur le plan de la rentabilité lorsque l'on ajoutait la TEP avec FDG aux batteries de tests pré-opératoires que l'on fait subir aux patients atteints d'un cancer du poumon.
$\mathrm{L}$ ung cancers are estimated to account for $15 \%$ of all cancers (17\% in men, $12 \%$ in women) and $28 \%$ of cancer mortality. The mainstay of lung cancer therapy is still surgery, and the strongest prognostic indicator for survival is whether the cancer can be completely resected. Computed tomography (CT) is still the imaging modality of choice in the study of the tumour itself, and detecting lymph node and extra thoracic metastases $(1,2)$. However, in patients with solitary pulmonary nodules, CT is often unhelpful in differentiating benign from malignant causes, except in the minority of cases in which benign appearing calcification can be identified. In addition, the sensitivity and specificity of CT in staging lung cancer are $67 \%$ (range $61 \%$ to $73 \%$ ) and $73 \%$ (range $62 \%$ to $80 \%$ ), respectively (2-6). This results in a significant number of patients being diagnosed as operable who in fact turn out during surgery to be inoperable. There are clearly large personal and financial costs attached to this mis-staging. The limitations of CT (and magnetic resonance imaging $[\mathrm{MRI}])$ staging in lung cancer are well recognized and stem from the uncertainty in detecting lymph node metastases from node size alone. Normal-sized lymph nodes can contain islands of malignant cells, and enlarged lymph nodes can be enlarged secondary to nonmalignant processes such as inflammation. This has led to the increasing use of "metabolic imaging" with positron emission tomography (PET) in a number of cancers, particularly nonsmall cell carcinoma of the lung.

\section{PET}

Cyclotron-produced, proton-rich radioisotopes decay to their ground state by either emitting a positively charged beta particle called a positron (eg, ${ }^{18}$ Fluorine) or capturing an electron and converting the extra proton to a neutron (eg, ${ }^{111}$ Indium). In positron decay the emerging $\beta+$ particle almost immediately combines with a free electron (e-) and annihilates yielding two gamma rays each of $0.511 \mathrm{M}_{\mathrm{ev}}$ energy. The fact that these gamma rays travel in opposite directions at $180^{\circ}$ to each other makes PET possible. The same filtered back projection reconstruction algorithms used in CT are used in PET. One unique feature of PET compared with other nuclear medicine imaging techniques is that the images can be corrected for tissue attenuation of the gamma rays with PET. It is, therefore, possible to measure absolute concentration of radioisotopes in tissue in counts per minute/mL with PET. This is important, for example, when the uptake of an isotope by a tumour is being measured.

\section{$\left[{ }^{18} \mathrm{~F}\right]$ FLUORO-2-DEOXYGLUCOSE UPTAKE IN MALIGNANT CELLS}

It has been known for many years that cancer cells use glucose at a much higher rate than normal cells (7). This is due in part to hypoxic tissue in the tumour, and, in part, to a genetically induced increase in the tumour cell membrane glucose transporter and an increase in the enzyme hexokinase (Figure 1). These changes are responsible for the marked increase in glycolysis in malignant cells. Deoxyglucose (DG) behaves like native glucose in the early phase of glycolysis. It is transported by the glucose transporter into the cell and converted to DG-6-phosphate by hexokinase. At this point, the metabolism of DG stops, and there is a build up of DG-6-phosphate that reflects glucose metabolism. Thus, when $\left[{ }^{18} \mathrm{~F}\right]-\mathrm{DG}$ (FDG) is injected intravenously, its accumulation in tissue reflects glucose metabolism.

PET scans with FDG have proven useful in a number of malignancies to determine

- whether a mass is malignant (lung nodule);

- whether a malignant tumour has metastasized (staging);

- whether malignancy has recurred (Is it just scar tissue from previous treatment or a recurrent malignancy?); and

- the response to therapy (If lack of response can be detected early, the treatment can be changed).

\section{SOLITARY LUNG NODULE, IS IT MALIGNANT?}

An estimated 130,000 new solitary pulmonary nodules are diagnosed each year in the United States. Approximately $40 \%$ to $50 \%$ of these are benign (8). With nodules larger than $2 \mathrm{~cm}$ in diameter, CT morphology and biopsy provide a definitive diagnosis in up to $90 \%$ of patients $(9,10)$, but, with smaller lesions, the diagnostic yield can be as low as $25 \%$. The false negative rate, even with large nodules, can be as high as $29 \%$ (11). Fine needle aspiration of lung masses is not without risk. In a recent study of 130 consecutive CTguided fine needle biopsies, $43 \%$ of the patients developed a pneumothorax, and $43 \%$ of these required a chest drain and a mean of six days' hospitalization (12). Fine needle aspiration also frequently fails to establish a definitive benign diagnosis, with 'nonspecific' cytology reports leaving a significant doubt in the mind of the referring physician (12).

From the literature, the sensitivity and specificity of FDG PET in the investigation of solitary pulmonary nodules are $96 \%$ and $77 \%$, respectively. Table 1 contains a compilation 
of nine studies on a total of 488 patients with lung nodules (13-21).

The striking finding in these studies is the low incidence of false negative PET scans - only 16 of 358 nodules proved to be malignant at surgery or biopsy. The majority of the false positive scans were due to granuloma.

We have recently reviewed our own experience with FDG PET and have demonstrated a sensitivity of $93 \%$ and a specificity of $86 \%$ for the diagnosis of malignant lesions (unpublished data). The three significant false positives in our group were due to bacterial infection. These results, as well as those described in Table 1, are based on visual evaluation of FDG PET images. Semiquantitative analysis has also been used to make the evaluation more objective. In our series, the sensitivity with semiquantitative analysis (lesion to background ratio) increased to $96 \%$ (not significantly different from visual evaluation). Other studies have also failed to show a significant improvement with semiquantitative analysis (22).

Figure 2 demonstrates the typical PET findings in a lung carcinoma, with increased uptake in the nodule in the left lower lobe. In Figure 3, a $3 \mathrm{~cm}$ nodule on CT is shown to be 'cold' with FDG PET. Biopsy of this mass was negative, and follow-up CT one year later showed no change in size, with some new features suggestive of round atelectasis.

PET scanning with FDG in the investigation of lung nodules has become routine in some institutions, including our own. It is also significant that many third party insurers in the United States now fund PET scans for this purpose. This is likely to result in the greater availability of FDG PET scanning facilities.

\section{MEDIASTINAL STAGING}

Once a lung mass has been shown to be malignant the next critical step is to determine whether there has been spread to the mediastinum or beyond. Table 2 is a compilation of seven studies on 286 patients in whom a final diagnosis was made at biopsy and or surgery (19,23-28). All of the studies used both PET with FDG and CT.

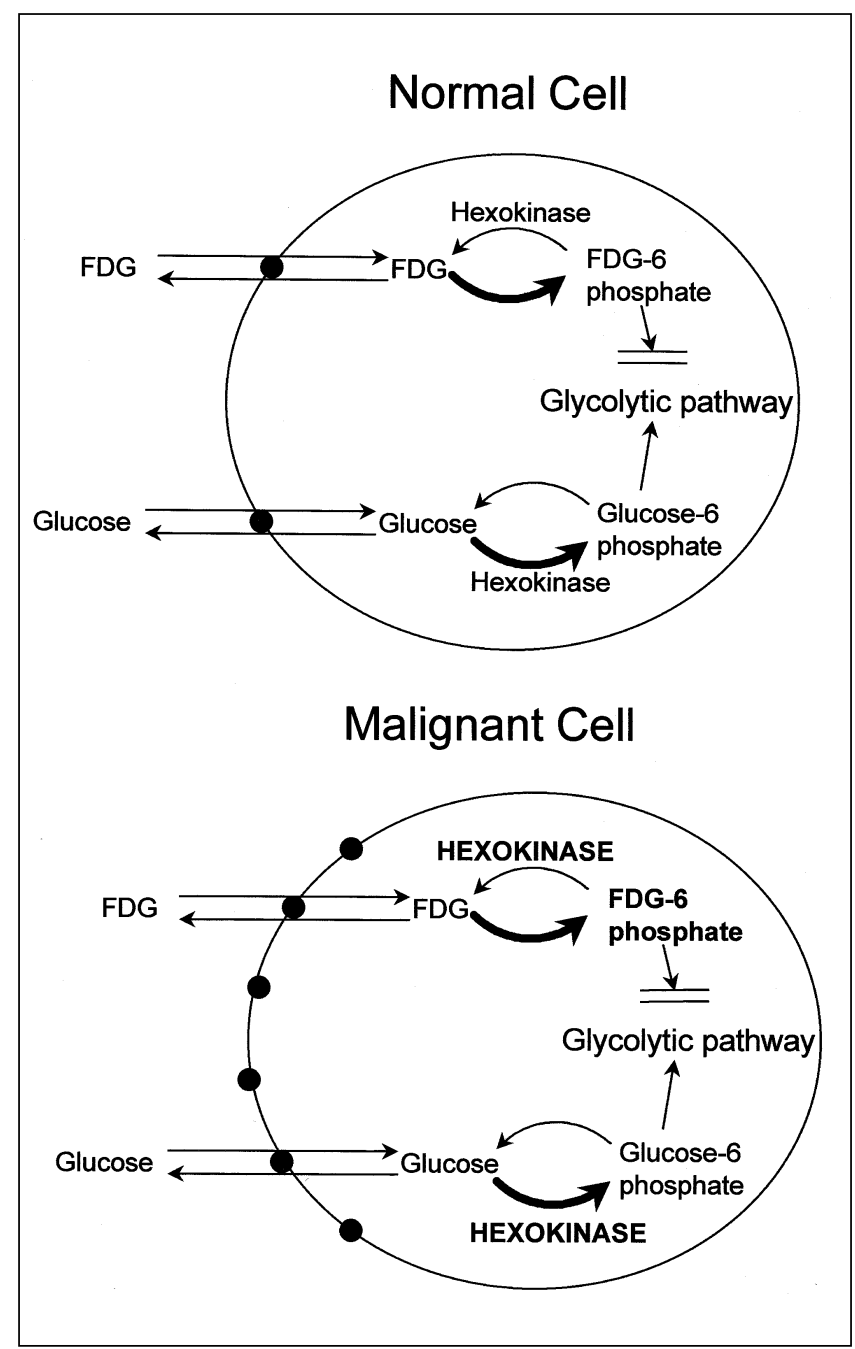

Figure 1) Uptake of ${ }^{18}$ F-fluoro-2-deoxyglucose (FDG) by normal and malignant cells. Increased activity of cell membrane glucose transporters and of intracellular hexokinase in malignant cells leads to increased production of FDG-6-phosphate, which is trapped in the cell because it cannot progress further along the glycolytic pathway

\section{TABLE 1}

\section{Detection of malignancy in lung nodules with positron emission tomography and ${ }^{18}$ F-fluoro-2-deoxyglucose}

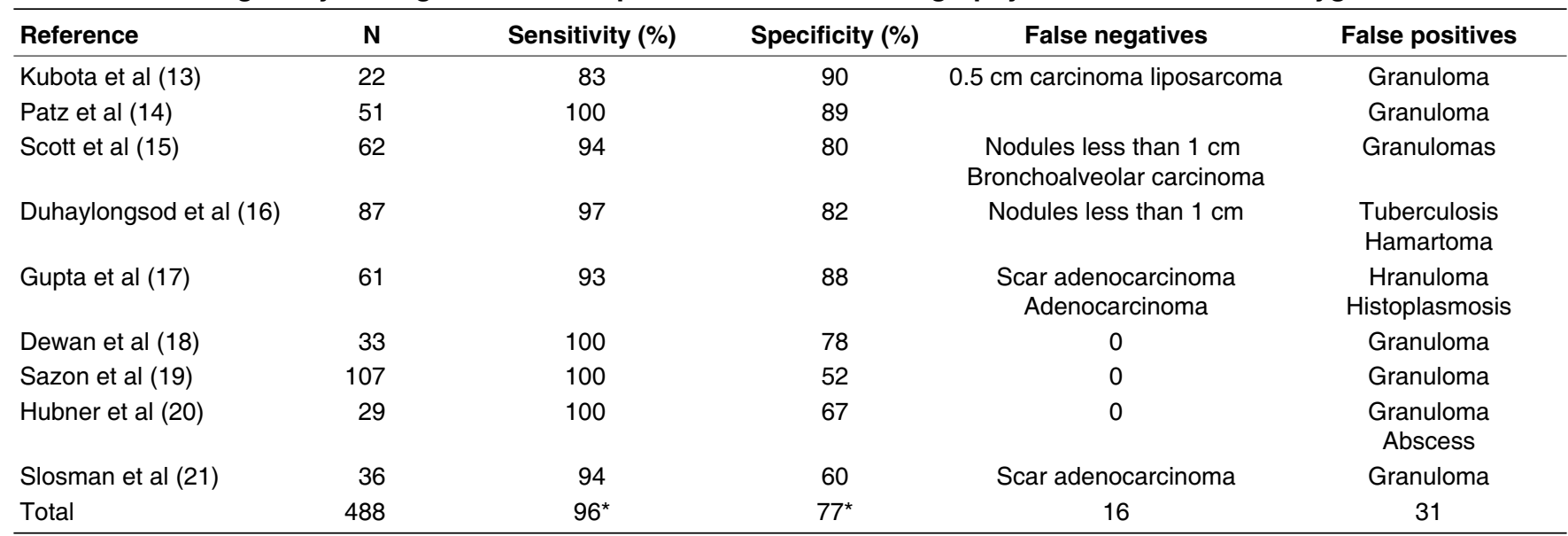

*Means weighted for the number of patients in the study 

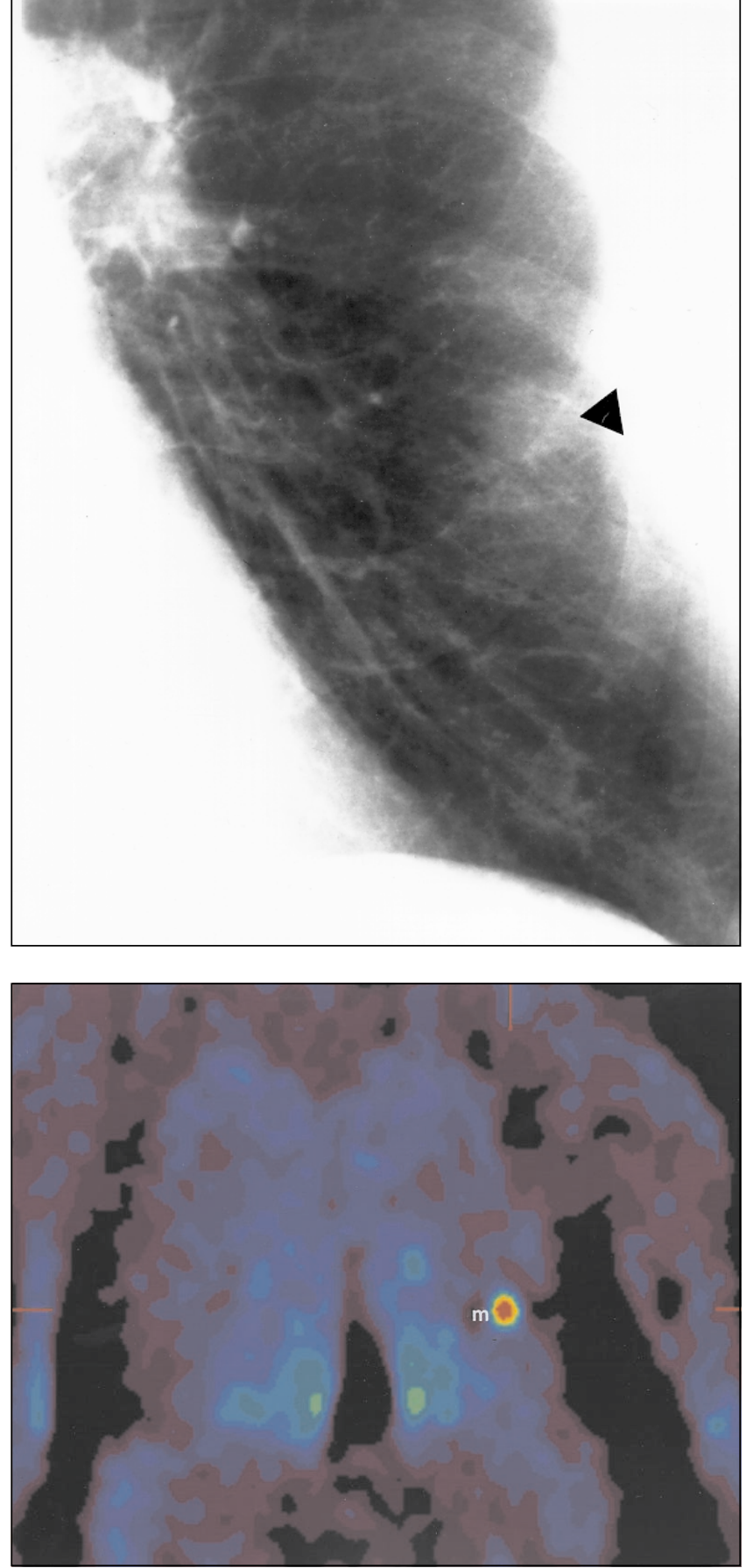

Figure 2) Top Chest $x$-ray demonstrates a small 'coin lesion' in the left lower lobe (arrow). Bottom Coronal ${ }^{18}$ F-fluoro-2deoxyglucose positron emission tomography shows a focus of intense activity in this malignant lesion $(m)$. Areas of less intense activity seen medially are due to normal myocardial uptake of ${ }^{18}$ F-fluoro-2-deoxyglucose

The sensitivity and specificity for PET were $89 \%$ and $94 \%$, respectively, and for CT $65 \%$ and $83 \%$, respectively. The figures for CT are similar to those published in previous studies (2-6). The majority of the false negative PET scans turned out to be microscopic metastases in normal-sized
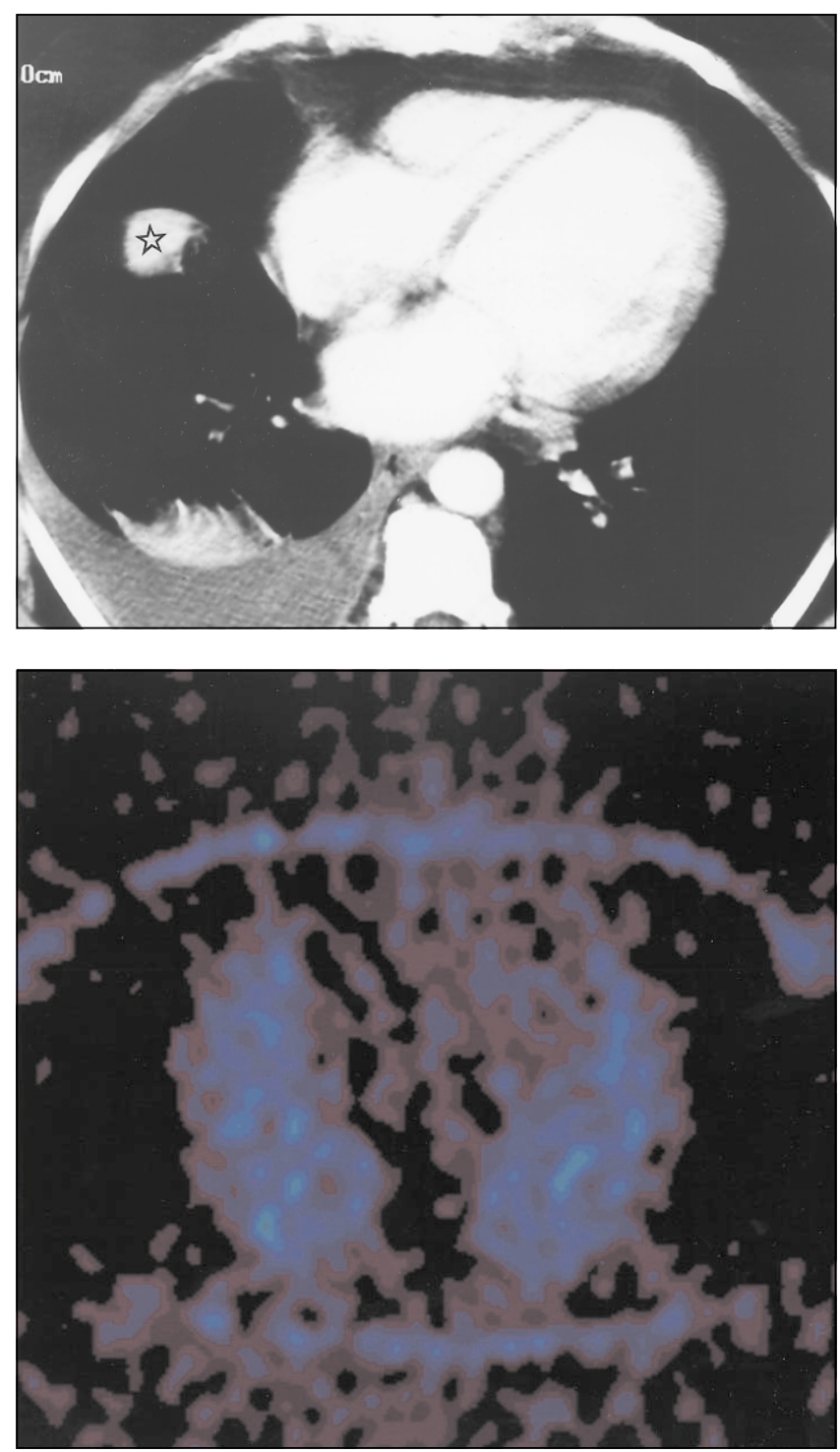

Figure 3) Top A $2.6 \mathrm{~cm}$ nodule is visible in the right lower lobe on computed tomography (star). There is also peripheral atelectasis and a pleural effusion. Bottom Normal low level pulmonary uptake is seen on the corresponding axial positron emission tomography image, consistent with a benign mass. Cytology of this mass was negative, and follow-up computed tomography showed stable appearances

lymph nodes. The false positive rate for PET in the mediastinal lymph nodes is low, and is usually due to either granuloma or reactive inflammatory change. However, the false positive rate in the lung hilum is higher because of reactive inflammatory change in the hilar nodes (24). Figure 4 illustrates both the CT and FDG PET findings in a patient with a bronchoalveolar carcinoma of the right lung, with metastatic involvement of the hilum and subcarinal nodes visible on both modalities. Figure 5 demonstrates a mediastinal node with a short-axis diameter of $8 \mathrm{~mm}$, which is below the 10 $\mathrm{mm}$ threshold used to diagnose malignant involvement with CT. FDG PET, however, clearly shows a focus of increased activity at this site, consistent with metastatic involvement. 
TABLE 2

Staging of mediastinal nodes with positron emission tomography (PET) and computed tomography (CT)

\begin{tabular}{|c|c|c|c|c|c|}
\hline \multirow[b]{2}{*}{ Reference (number) } & \multirow[b]{2}{*}{$\mathbf{N}$} & \multicolumn{2}{|c|}{ Sensitivity (\%) } & \multicolumn{2}{|c|}{ Specificity (\%) } \\
\hline & & PET & CT & PET & CT \\
\hline Wahl et al (23) & 23 & 82 & 64 & 81 & 44 \\
\hline Valk et al (25) & 76 & 83 & 63 & 94 & 73 \\
\hline Chin et al (26) & 30 & 78 & 56 & 81 & 86 \\
\hline Sazon et al (19) & 32 & 100 & 81 & 100 & 56 \\
\hline Steinert et al (28) & 47 & 89 & 57 & 99 & 94 \\
\hline $\begin{array}{l}\text { Mean weighted for the number of } \\
\text { patients in the study }\end{array}$ & 286 & 89 & 65 & 94 & 83 \\
\hline
\end{tabular}
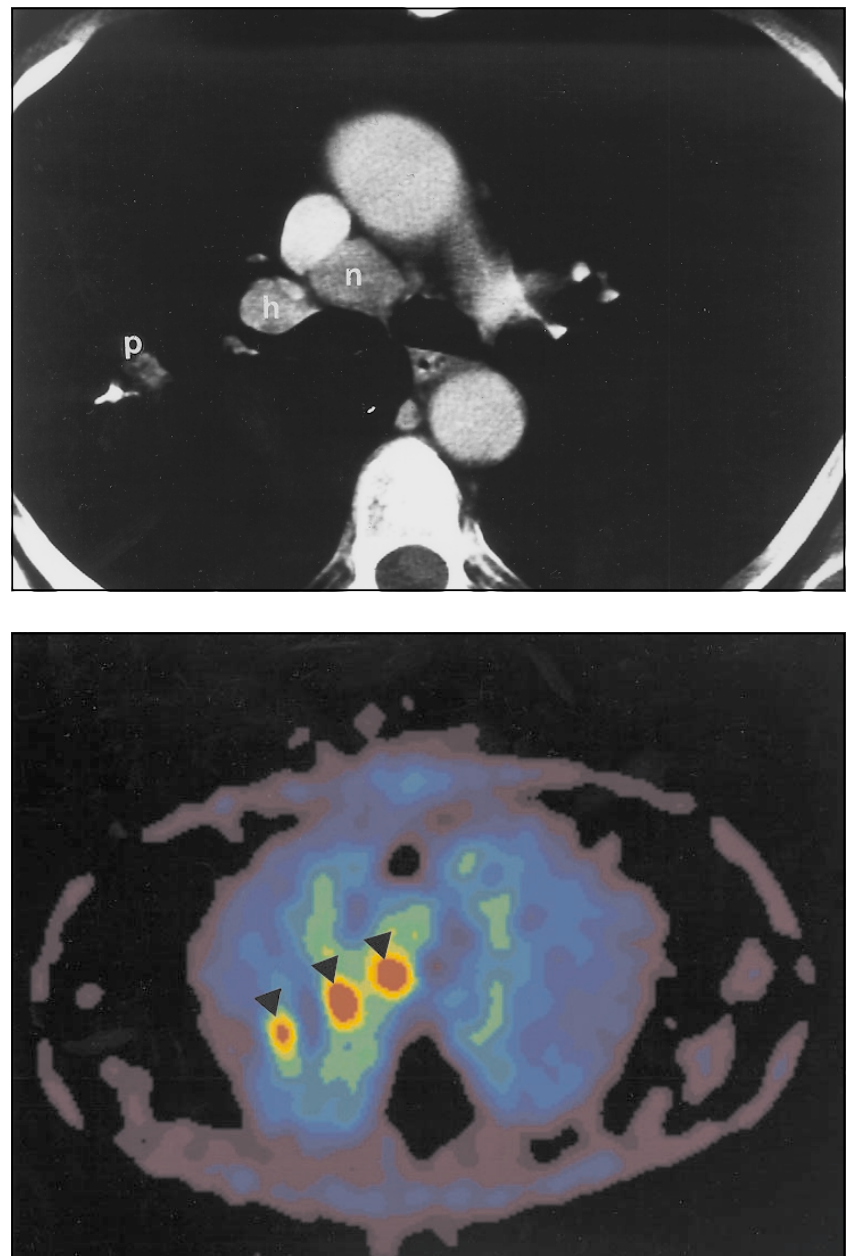

Figure 4) Top Computed tomography in this patient with bronchoalveolar carcinoma shows a pulmonary mass ( $p)$, right hilar node $(h)$ and subcarinal node $(n)$ on the same axial plane. Bottom The corresponding axial positron emission tomography scan shows increased uptake at all three sites (arrows), indicating malignant adenopathy

\section{DISTANT METASTASES}

Distant metastases from nonsmall cell carcinoma are common, particularly to the other lung, adrenal glands and bone. With whole body PET scans, the axial skeleton and abdomen are in the field of view, and these areas can easily be examined for metastases. Metastatic involvement of the ad-
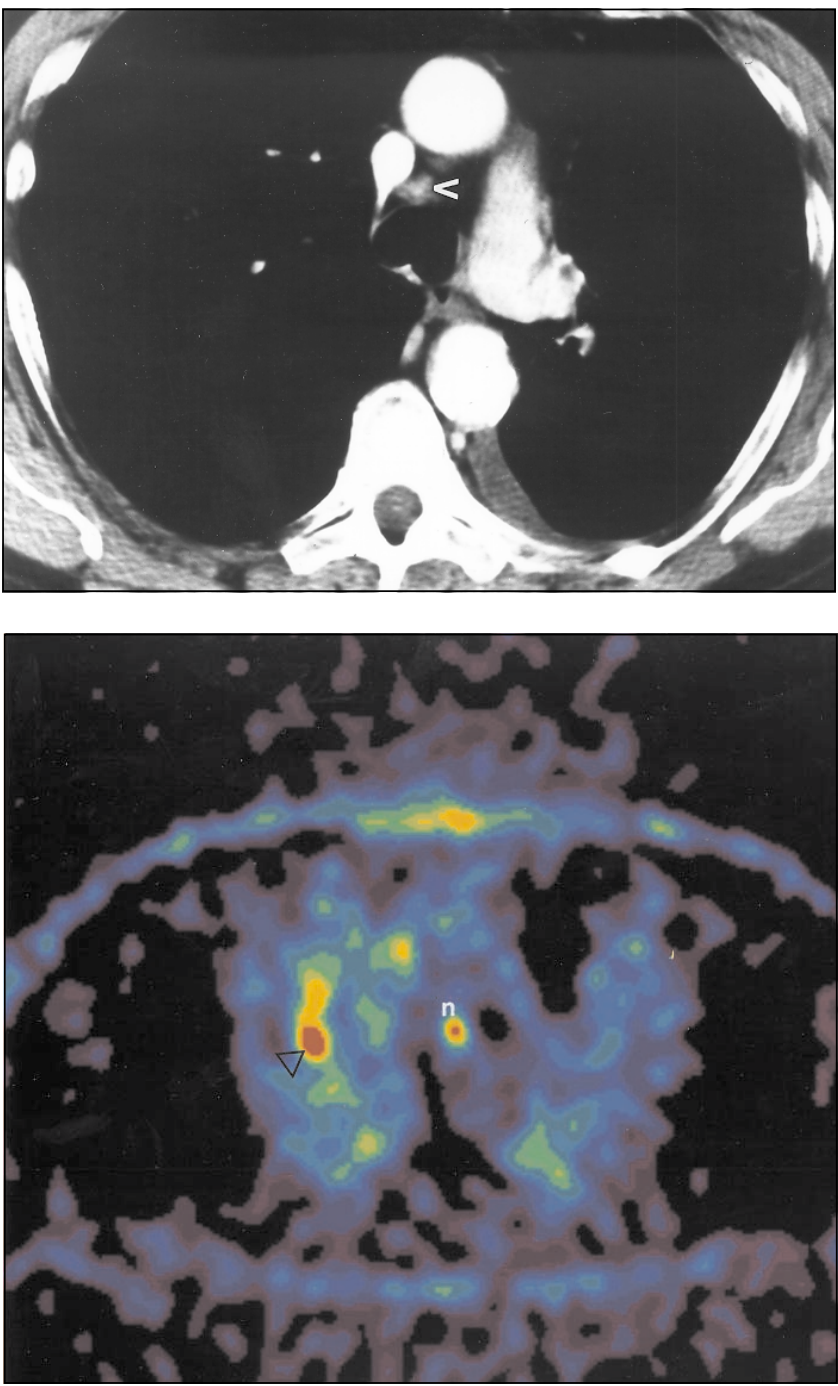

Figure 5) Top Computed tomography demonstrates an $8 \mathrm{~mm}$ pretracheal node (arrowhead), smaller than the $10 \mathrm{~mm}$ 'threshold' for malignancy. Bottom Positron emission tomography in the same patient shows increased uptake in the node (n), consistent with metastatic disease. The small primary tumour is also visible on the positron emission tomography examination (open arrow)

renal gland is illustrated in Figure 6. In three recent publications $(25,27,29)$, PET with FDG identified proven distant metastases in 58 of 242 (23\%) patients with lung carcinoma. 


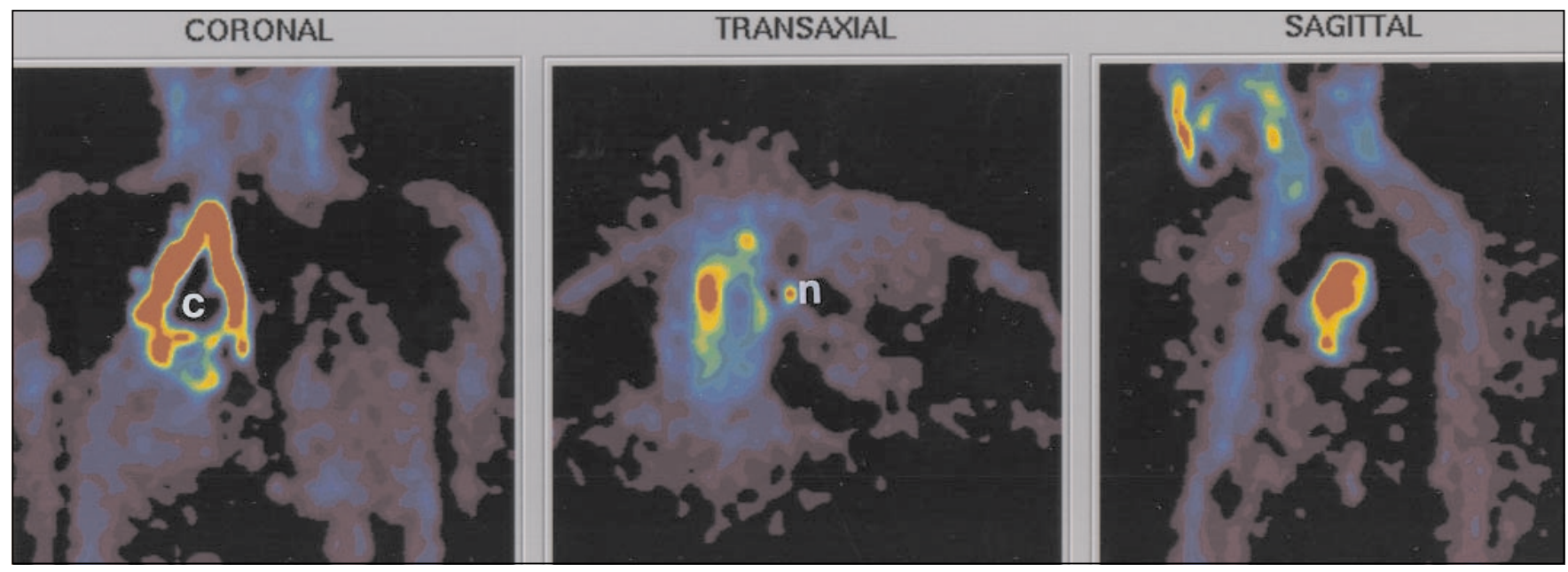

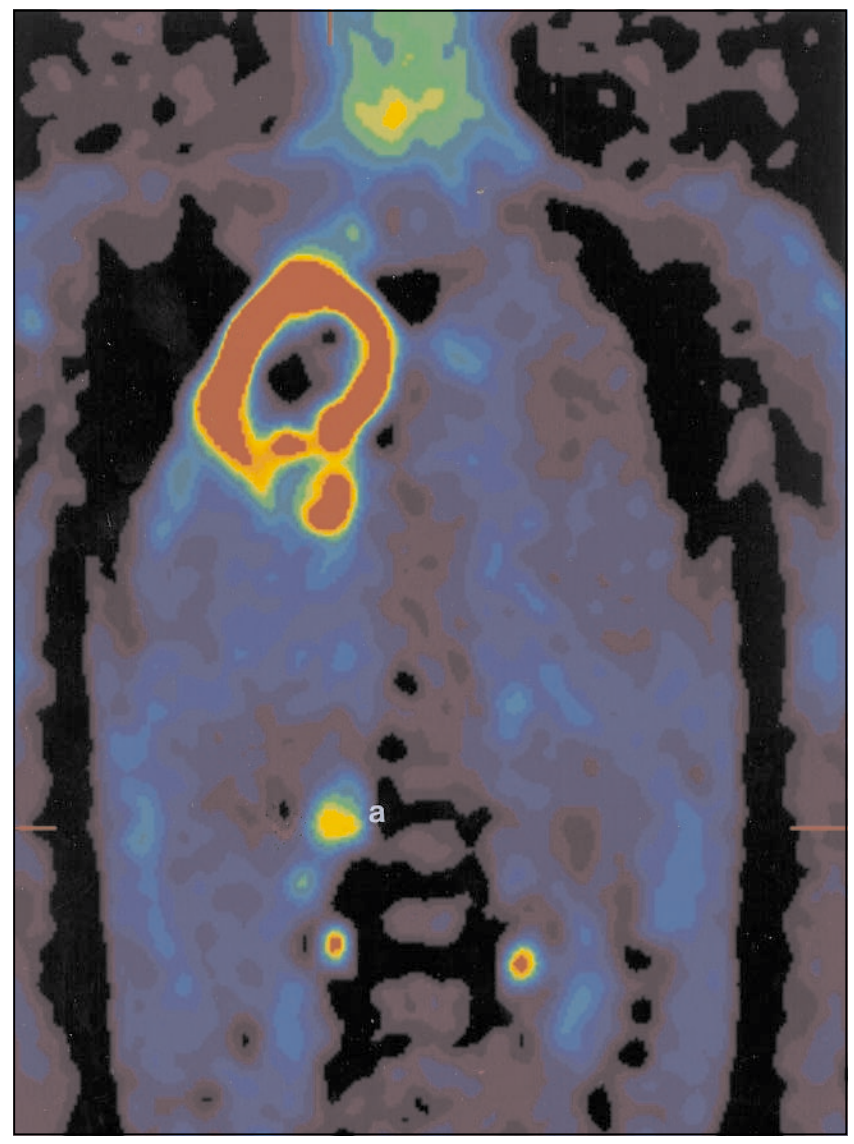

One study reported significant changes in patient management based on PET results in $43 \%$ of patients (29), while another reported significantly different management decisions in $25 \%$ (27). The accuracy of FDG PET for detecting bone metastases was $96 \%$ in a recent study, compared with $66 \%$ for bone scanning, with the difference due to the much higher specificity of PET (30).

\section{RECURRENT DISEASE:} IS IT SCAR TISSUE OR CANCER?

It is frequently very difficult to determine by CT or ddMRI whether a patient with previous surgery for lung cancer has a recurrent cancer, for example in the bronchial
Figure 6) Top Coronal, axial and sagittal positron emission tomography images demonstrate a large tumour of the right upper lobe with mediastinal lymphadenopathy $(n)$. The central 'cold' area $(c)$ in the primary tumour represents necrosis. Side Coronal image in the same patient shows a focus of increased activity in the right adrenal gland (a), consistent with metastasis. The two areas of increased uptake below this are due to normal activity in the renal pelvis

stump, or just scar tissue. PET detects increased tissue metabolism and is, therefore, ideally suited to differentiate between scar tissue and recurrent cancer. Patz et al (31) and Duhaylongsod et al (16) specifically examined the usefulness of PET in this situation. They reported positive PET scans in 40 of 41 patients who were subsequently shown to have histologically positive recurrent cancer. There were no false positive scans. Figure 7 illustrates a case in which PET was essential in diagnosing the recurrence of tumour in the bronchial stump postpneumonectomy. PET has also proved very useful in detecting recurrent cancer in the head and neck (32), and bowel (33).

\section{RESPONSE TO TREATMENT}

In patients with cancer, it is important to detect early response or failure to respond to chemotherapy or radiotherapy so that treatment can be continued or be modified. There is little change in the size or density of tumours in the early stages of therapy, and, therefore, MRI or CT are of little value in monitoring early response. Metabolic markers, however, such as FDG are being used for this purpose. Shields et al (34) recently used FDG and carbon-11-thymidine in four patients with small cell carcinoma of the lungs to measure response to chemotherapy. One week after the start of chemotherapy, they showed a decline in both metabolism (FDG) and cell proliferation rate (thymidine), in three patients who subsequently responded to therapy. Others have used FDG in patients undergoing radiotherapy for nonsmall cell lung cancer (35). They showed that patients who had a normal FDG uptake after therapy survived two years, whereas $50 \%$ of patients with tumour hypermetabolism after therapy died dur- 


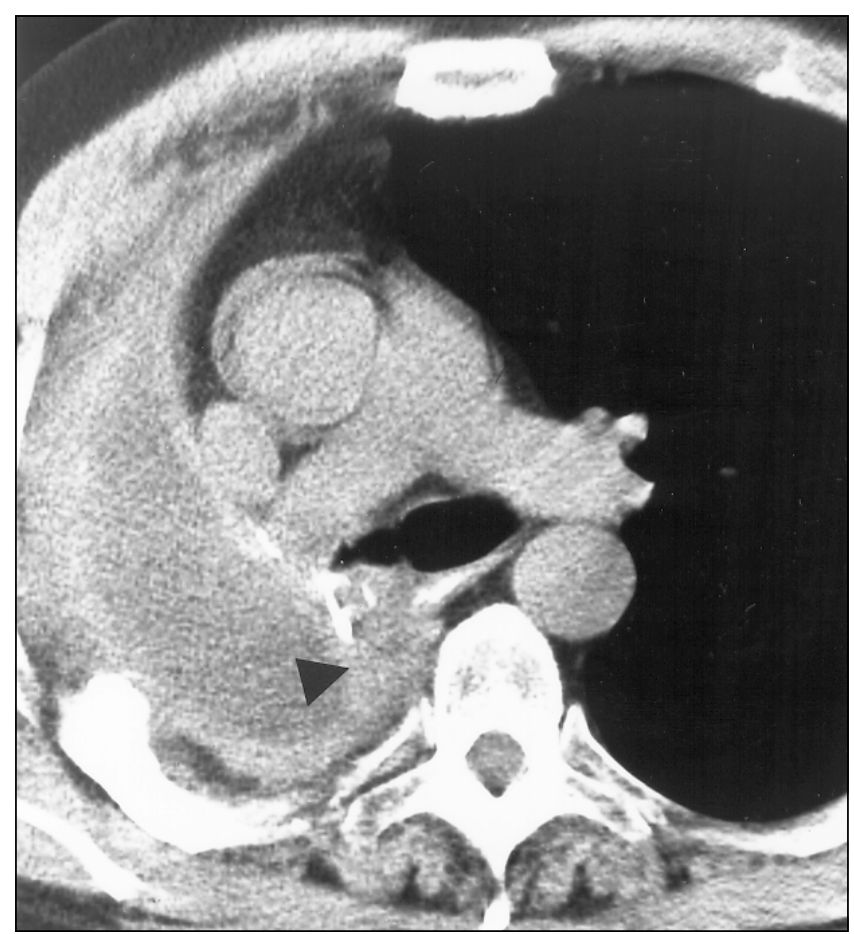

ing the two years. Frank et al (36) used FDG uptake following therapy as a marker to determine whether further therapy was required.

\section{COST EFFECTIVENESS OF PET}

Apart from the obvious human costs of unnecessary thoracic surgery, there are also substantial financial savings. Duhaylongsod et al (16) and Gambhir et al (37) have analyzed the potential savings of adding a FDG PET scan to the preoperative protocol in patients with nonsmall cell lung cancer. The cost reductions reported were $5 \%$ to $25 \%$.

\section{CONCLUSIONS}

From our own experience and from the literature, FDG PET has had an impact on the investigation of lung cancer. It will never replace CT in the investigation of lung cancer patients because CT adds so much anatomical and structural detail, which is vital to surgical planning. The metabolic information from PET complements these anatomical data.

In Canada, there is only one PET centre that performs routine clinical PET in patients with cancer (Hamilton Health Sciences Corporation). However, a second site (Sherbrooke) will open very shortly, and other centres in Canada are seriously considering obtaining PET scanners. The cost of PET tomographs is slowly coming down, and FDG is now commercially available almost anywhere in North America from radiopharmaceutical suppliers. This obviates the needs for expensive on site cyclotrons and will greatly increase the availability of PET in the near future.

\section{REFERENCES}

1. Webb WR, Gatsonis C, Zerhouni EA, et al. CT and MR imaging in staging non-small cell bronchogenic carcinoma. Report of the Radiologic Diagnostic Oncology Group. Radiology 1991;178:705-13.

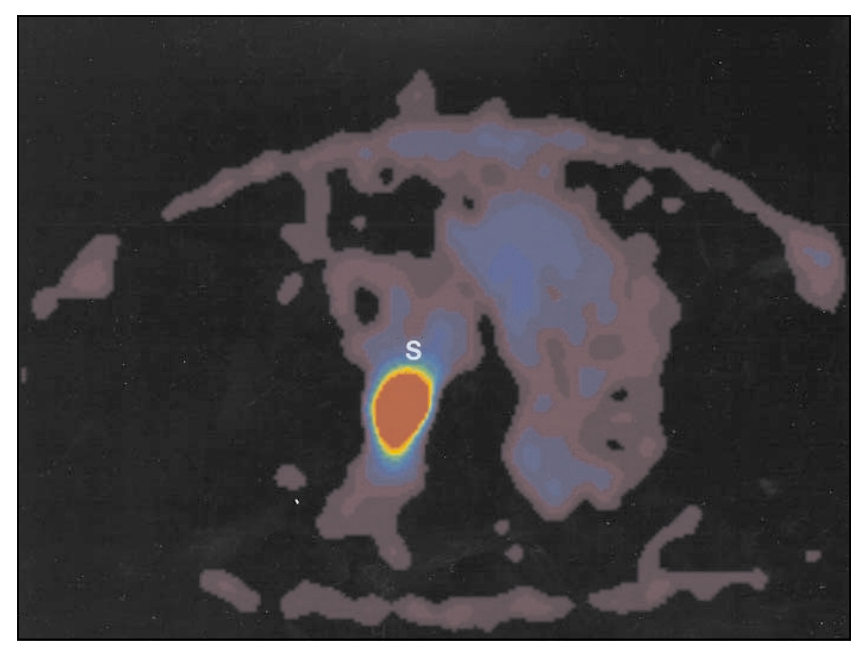

Figure 7) Left Soft tissue thickening (arrow) is visible adjacent to the right bronchial stump in this patient who had a previous right pneumonectomy for bronchogenic carcinoma. Because of marked postoperative pleural thickening, it is impossible to distinguish a recurrent tumour from scarring. Right Corresponding axial positron emission tomography demonstrates intense focal activity at the site of soft tissue thickening $(s)$, consistent with disease recurrence

2. McLoud TC, Bourgouin PM, Greenberg RW, et al. Bronchogenic carcinoma: analysis of staging in the mediastinum with CT by correlative lymph node mapping and sampling. Radiology 1992;182:319-23.

3. Gross B, Glazer G, Orringer M, Spisary D, Flint A. Bronchogenic carcinoma metastatic to normal-sized lymph nodes: frequency and significance. Radiology 1988;166:71-4.

4. Primack SL, Lee KS, Logan PM, Miller RR, Muller NL. Bronchogenic carcinoma: utility of CT in the evaluation of patients with suspected lesions. Radiology 1994;193:795-800.

5. White P, Adams H, Crane M, Butchart E. Preoperative staging of carcinoma of the bronchus: can computed tomography scanning reliably identify stage III tumours? Thorax 1994;49:951-7.

6. Dillemans B, Deneffe G, Verschakelen J, Decramer M. Value of computer tomography and mediastinoscopy in preoperative evaluation of mediastinal nodes in non-small cell lung cancer. A study of 569 patients. Eur J Cardiothorac Surg 1994;8:37-42.

7. Warburg O. On the origin of cancer cells. Science 1956;123:309-14.

8. Lillington GA. Pulmonary nodules: solitary and multiple. Clin Chest Med 1982;3:361-7.

9. Fletcher EC, Levin DC. Flexible fibreoptic bronchoscopy and fluoroscopically guided transbronchial biopsy in the management of solitary pulmonary nodules. West J Med 1982;136:477-83.

10. Wallace JM, Deutsch AL. Flexible fibreoptic bronchoscopy and percutaneous needle lung aspiration biopsy for evaluating the solitary pulmonary nodule. Chest 1982;81:665-71.

11. Calhoun P, Feldman PS, Armstrong P, et al. The clinical outcome of needle aspiration of the lung when cancer is not diagnosed. Ann Thorac Surg 1986;41:592-6.

12. Larscheid RC, Thorpe PE, Scott WJ. Percutaneous transthoracic needle aspiration biopsy: a comprehensive review of its current role in the diagnosis and treatment of lung tumors. Chest 1998;114:704-9.

13. Kubota K, Matsuzawa T, Fujiwara T, et al. Differential diagnosis of lung tumor with positron emission tomography: a prospective study. J Nucl Med 1990;31:1927-33.

14. Patz EF Jr, Lowe VJ, Hoffman JM, et al. Focal pulmonary abnormalities: evaluation with F-18 fluorodeoxyglucose PET scanning. Radiology 1993;188:487-490.

15. Scott WJ, Schwabe JL, Gupta NC, Dewan NA, Reeb SD, Sugimoto JT and members of the PET-Lung Tumor Study Group. Positron emission tomography of lung tumors and mediastinal lymph nodes using $\left[{ }^{18}\right.$ F]fluorodeoxyglucose. Ann Thorac Surg 1994;58:698-703.

16. Duhaylongsod FG, Lowe VJ, Patz EF Jr, Vaughn AL, Coleman RE, Wolfe WG. Detection of primary and recurrent lung cancer by means 
of F-18 fluorodeoxyglucose positron emission tomography (FDG PET). J Thorac Cardiovasc Surg 1995;110:130-40.

17. Gupta NC, Maloof J, Gunel E. Probability of malignancy in solitary pulmonary nodules using fluorine-18-FDG and PET. J Nucl Med 1996;37:943-8

18. Dewan NA, Reeb SD, Gupta NC, Gobar LS, Scott WJ. PET-FDG imaging and transthoracic needle lung aspiration biopsy in evaluation of pulmonary lesions. A comparative risk-benefit analysis. Chest 1995;108:441-6.

19. Sazon DA, Santiago SM, Soo Hoo GW, et al. Fluorodeoxyglucosepositron emission tomography in the detection and staging of lung cancer. Am J Respir Crit Care Med 1996;153:417-21.

20. Hubner KF, Buonocore E, Sing SK, Gould HR, Cotten DW. Characterization of chest masses by FDG positron emission tomography. Clin Nucl Med 1995;20:293-8.

21. Slosman DO, Spiliopoulos A, Couson F, et al. Satellite PET and lung cancer: a prospective study in surgical patients. Nucl Med Commun 1993;14:955-61.

22. Lowe VJ, Hoffman JM, DeLong DM, Patz EF, Coleman RE. Semiquantitative and visual analysis of FDG-PET images in pulmonary abnormalities. J Nucl Med 1994;35:1771-6.

23. Wahl RL, Quint LE, Greenough RL, Meyer CR, White RI, Orringer MB. Staging of mediastinal non-small cell lung cancer with FDG PET, CT, and fusion images: preliminary prospective evaluation. Radiology 1994;191:371-7.

24. Patz ED Jr, Lowe VJ, Goodman PC, Herndon J. Thoracic nodal staging with PET imaging with ${ }^{18} \mathrm{FDG}$ in patients with bronchogenic carcinoma. Chest 1995; 108:1617-21.

25. Valk PE, Pounds TR, Hopkins DM, et al Staging non-small cell lung cancer by whole-body positrom emission tomographic imaging. Ann Thorac Surg 1995;60:1573-82.

26. Chin R Jr, Ward R, Keyes JW Jr, et al. Mediastinal staging of non-small-cell lung cancer with positron emission tomography. Am J Respir Crit Care Med 1995;152:2090-6.

27. Bury T, Dowlati A, Paulus P, et al. Whole-body ${ }^{18}$ FDG positron emission tomography in the staging of non-small cell lung cancer. Eur Respir J 1997;10:2529-34.

28. Steinert HC, Hauser M, Allemann F, et al. Non-small cell lung cancer: nodal staging with FDG PET versus CT with correlative lymph node mapping and sampling. Radiology 1997;202:441-6.

29. Lewis P, Griffin S, Marsden P, et al. Whole-body

${ }^{18} \mathrm{~F}$-fluorodeoxyglucose positron emission tomography in preoperative evaluation of lung cancer. Lancet 1994;344:1265-6.

30. Bury T, Barreto A, Daenen F, Barthelemy N, Ghaye B, Rigo P. Fluorine-18 deoxyglucose positron emission tomography for the detection of bone metastases in patients with non-small cell lung cancer. Eur J Nucl Med 1998;25:1244-7.

31. Patz EF Jr, Lowe VJ, Hoffman JM, Paine SS, Harris LK, Goodman PC. Persistent or recurrent bronchogenic carcinoma: detection with PET and 2-[F-18]-2-deoxy-D-glucose. Radiology 1994;191:379-82.

32. Anzai Y, Carroll WR, Quint DJ, et al. Recurrence of head and neck cancer after surgery or irradiation: prospective comparison of 2-deoxy-2-[F-18]fluoro-D-glucose PET and MR imaging diagnoses. Radiology 1996;200:135-41.

33. Delbeke D, Vitola JV, Sandler MP, et al. Staging recurrent metastatic colorectal carcinoma with PET. J Nucl Med 1997;38:1196-201.

34. Shields AF, Mankoff DA, Link JM, et al. Carbon-11-thymidine and FDG to measure therapy response. J Nucl Med 1998;39:1757-62.

35. Hebert ME, Lowe VJ, Hoffman JM, Patz EF Jr, Anscher MS. Positron emission tomography in the pretreatment evaluation and follow-up on nonsmall cell lung cancer patients treated with radiotherapy: preliminary findings. Am J Clin Oncol 1996;19:416-21.

36. Frank A, Lefkowitz D, Jaeger S, et al. Decision logic for retreatment of asymptomatic lung cancer recurrence based on positron emission tomography findings. Int J Radiat Oncol Biol Phys 1995;32:1495-512.

37. Gambhir SS, Hoh CK, Phelps ME, Madar I, Maddahi J. Decision tree sensitivity analysis for cost-effectiveness of FDG-PET in the staging and management of non-small-cell lung carcinoma. J Nucl Med 1996;37:1428-36. 


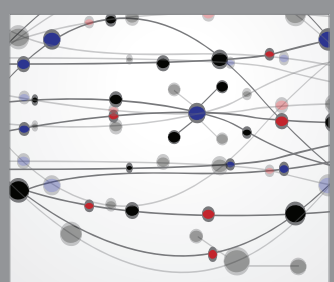

The Scientific World Journal
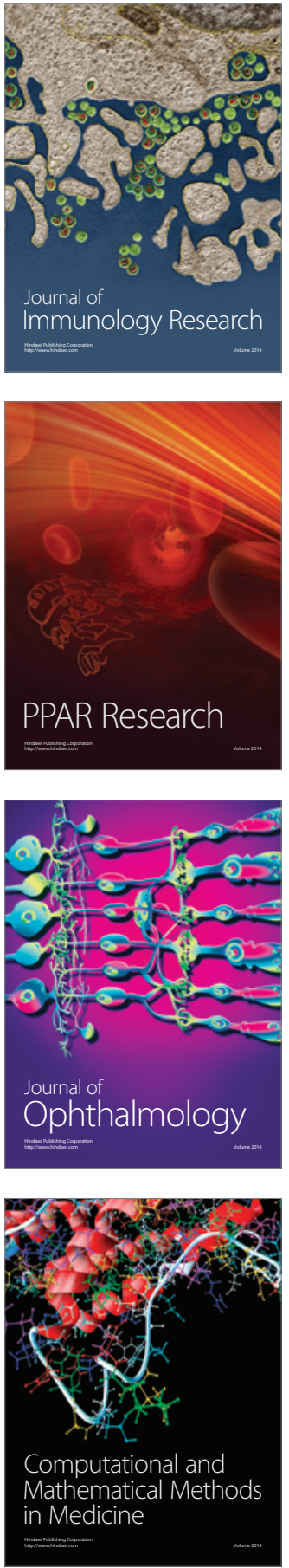

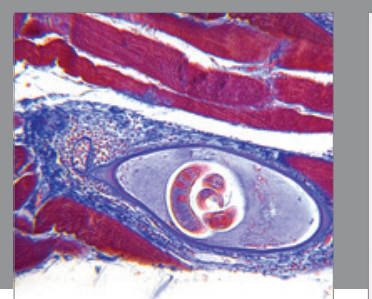

Gastroenterology Research and Practice

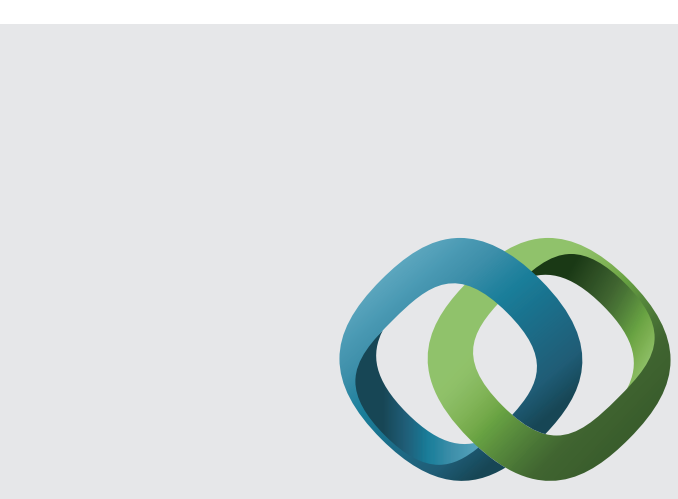

\section{Hindawi}

Submit your manuscripts at

http://www.hindawi.com
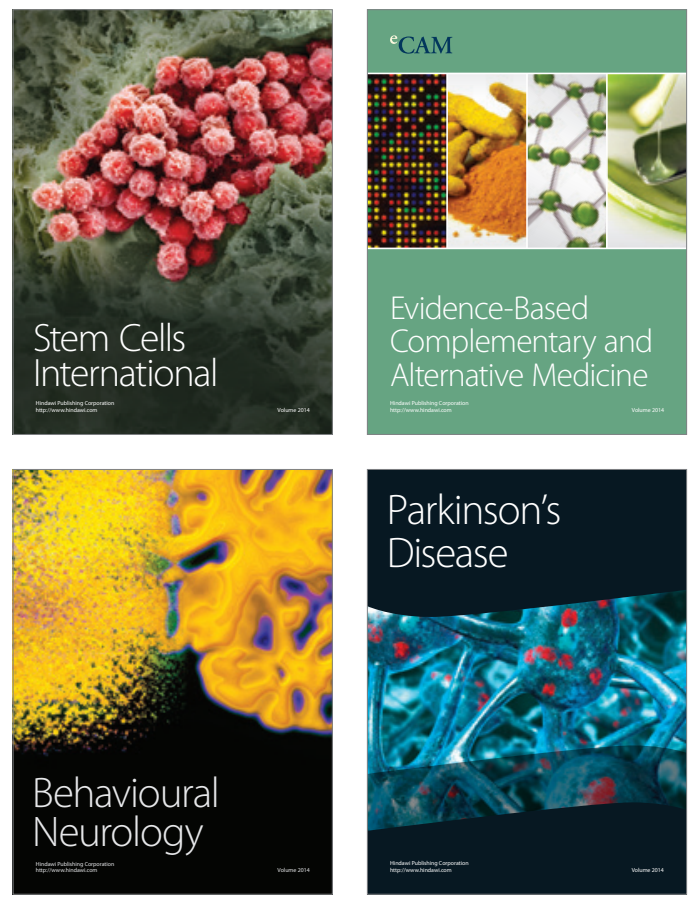
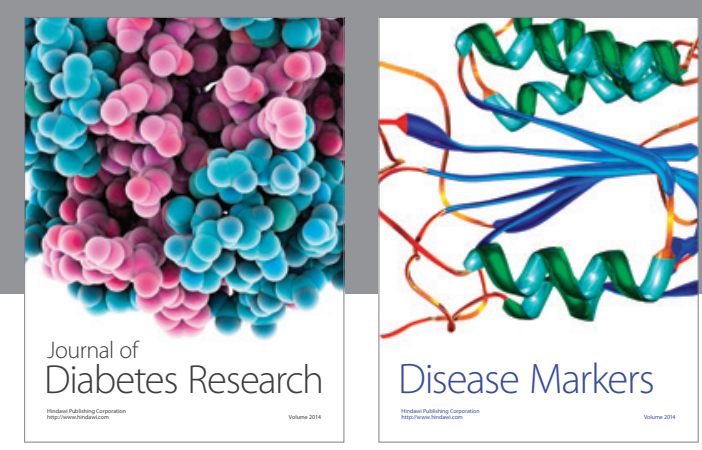

Disease Markers
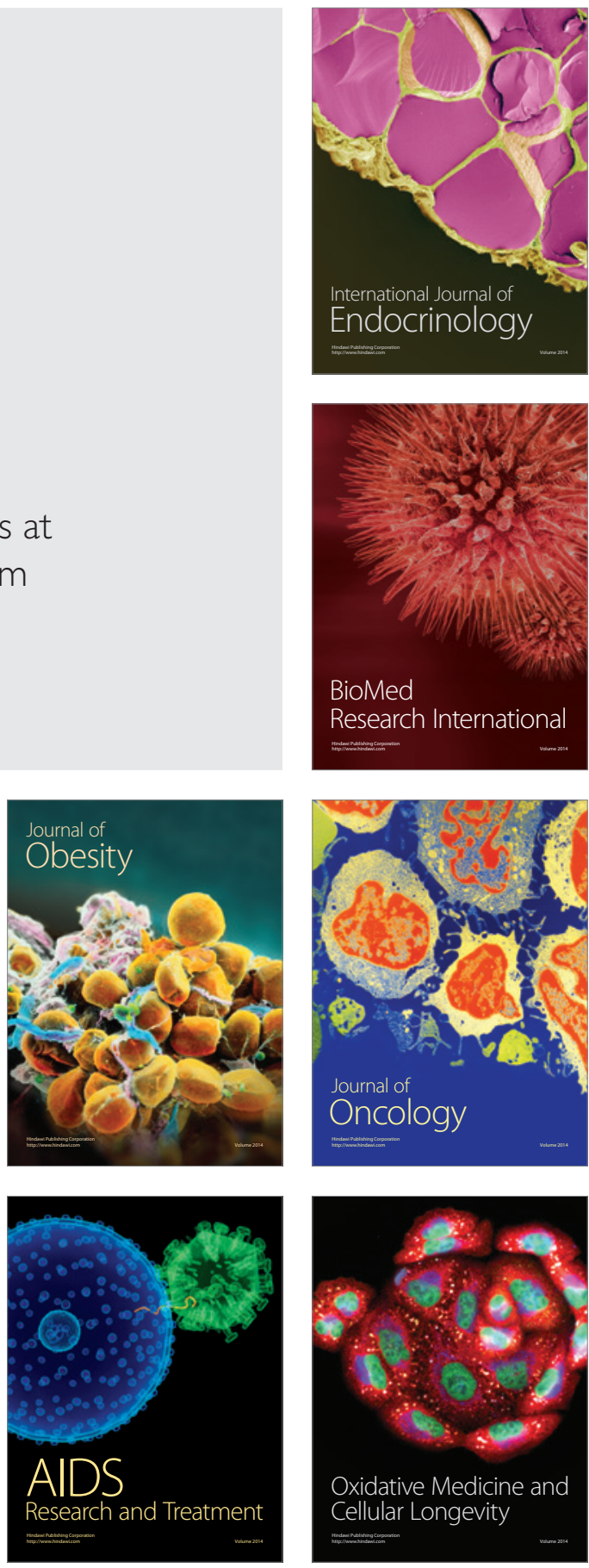